\title{
PERLINDUNGAN HUKUM KELOMPOK PETERNAK SAPI DALAM PERJANJIAN KEMITRAAN DENGAN UD.WIRAGUNA TERNAK SEJAHTERA
}

\author{
Pahrur Rizal \\ rizalpahrur@gmail.com \\ IAHN Gde Pudja Mataram
}

\begin{abstract}
Abstrak
Tujuan penelitian ini untuk mengetahui mekanisme perjanjian dan bentuk perlindungan hukum kelompok peternak sapi dalam perjanjian kemitraan dengan UD. Wiraguna Ternak sejahtera, jenis penelitian ini adalah normative empiris Mekanisme perjanjian penggemukan sapi antara kelompok peternak sapi dengan UD Ternak sejahtera (konsultan) diawali dengan membentuk kelompok, ketua kelompok inilah yang mewakili pembuatan perjanjian dengan konsultan yang akan memberikan pendampingan selama program penggemukan sapi. Upaya perlindungan hukum bagi para pihak, khususnya pihak Plasma sebagai pihak yang lemah dapat ditempuh melalui tiga mekanisme, yaitu (a)Penerapan ketentuan hukum administrasi dengan penegakkan aturan tentang, pembinaan, pengawasan oleh pemerintah, sebagai mana diatur dalam UU usaha mikro, kecil dan menengah, dan atau PP tentang kemitraan. (b)Penerapan ketentuan dalam UU no 8 tahun 1999 tentang Perlindungan konsumen. (c) Penerapan ketentuan hukum perdata, dengan melakukan gugatan pembatalan perjanjian ke Pengadilan Negeri.
\end{abstract}

Kata kunci : perlindungan hukum, peternak sapi

\section{A. Pendahuluan Latar Belakang}

Indonesia merupakan negara agraris yang kaya akan hasil pertanian,kehutanan, perkebunan, peternakan, dan perikanan. Kondisi alam tersebut memberikan peluang bagi sebagian besar masyarakat Indonesia untuk melakukan kegiatan usaha salah satunya di bidang peternakan. Peternakan merupakan sektor yang memiliki peluang sangat besar untuk dikembangkan sebagai usaha di masa depan. Kebutuhan masyarakat akan produk-produk peternakan akan semakin meningkat setiap tahunnya. Peternakan sebagai penyedia protein, energi, vitamin, dan mineral semakin meningkat seiring meningkatnya kesadaran masyarakat akan kebutuhan gizi guna meningkatkan kualitas hidupnya. 
Pembangunan sub-sektor peternakan pada dasarnya merupakan implementasi dan bagian dari kebijakan pembangunan pertanian yang memiliki nilai penting dalam ketahanan pangan dan berupaya untuk meningkatan kualitas sumberdaya manusia Indonesia. Penanganan masalah pangan menjadi sangat penting seiring dengan perubahan stuktural ekonomi (the structural change of economy), di mana dalam perubahan ini sektor pertanian berperan sebagai penyedia bahan baku yang mampu menciptakan dampak peningkatan nilai tambah melalui keterkaitan ke belakang dan ke depan (backward and forward linkages). Ini berarti sektor pertanian dalam arti luas bukan saja memiliki peran yang sangat strategis, namun juga memiliki peran yang sangat besar, terutama dalam usaha mengatasi masalah kekurangan pangan dan gizi yang masih dialami oleh sebagian besar penduduk Indonesia.

Salah satu hal yang menarik dalam perjalanan hukum Indonesia adalah muncul pengaturan tentang peternakan. Pengaturan bidang pertenakan yang muncul tidak hanya untuk melindungi dan meningkatkan kualitas sumber daya hewan; menyediakan pangan yang aman, sehat, utuh, dan halal; meningkatkan derajat kesehatan masyarakat, hewan, dan lingkungan; menyediakan jasa dan bahan baku industri; mengembangkan ilmu pengetahuan dan teknologi; meningkatkan pendapatan dan devisa negara;, melainkan pula memperluas kesempatan berusaha dan kesempatan kerja; serta meningkatkan kesejahteraan rakyat ${ }^{1}$.

Tata kelola peternakan yang melindungi peternak dan peternakan merupakan gambaran terhadap perlindungan kekayaan keanekaragaman hayati dan sumber daya alam yang melimpah secara terpadu dan terintegrasi berdasarkan wawasan Nusantara. Pengelolaan tersebut harus dapat memberikan kemanfaatan ekonomi, sosial, dan budaya dilaksanakan berdasarkan prinsip kehati-hatian, taat asas dan konsekuen dari pusat sampai daerah. Hal ini menuntut kalangan hukum untuk melakukan pendekatan interdisipliner dan lintas sektoral. Beberapa sektor yang terkait dapat

\footnotetext{
${ }^{1}$ Penjelasan Paragraf 3 Undang-Undang Nomor 18 Tahun 2009 tentang Peternakan Dan Kesehatan Hewan.
} 
disebutkan diantaranya sektor kependudukan, kesehatan, transmigrasi, pemukiman dan perumahan, pertambangan, perindustrian, pertanian, (peternakan) kehutanan, kelautan, perdagangan, perikanan, pengairan, penataan ruang, dan sektor-sektor lain ${ }^{2}$.

Patut dipahami bahwa peternakan layaknya pertanian yang lahir bersamaan dengan lahirnya masyarakat Indonesia yang muncul bermula dari pedesaan, peternakan mempunyai peran penting terhadap perbaikan kehidupan masyarakat yang menggantungkan hidupnya dalam bidang tersebut. Peternakan pula merupakan kekayaan keanekaragaman hayati yang sangat besar (mega biodiversity) berupa sumber daya hewan dan tumbuhan, sebagai anugerah sekaligus amanah Tuhan Yang Maha Esa. Kekayaan tersebut perlu dimanfaatkan dan dilestarikan dalam mewujudkan kesejahteraan seluruh rakyat Indonesia, sebagaimana tercantum dalam Pembukaan Undang-Undang Dasar Negara Republik Indonesia Tahun 1945.

Perlindungan hukum ditujukan pula demi terwujud dan terlaksananya kesejahteraan dengan peningkatan taraf hidup, terutama bila terkait kepada peternak agar terlepas dari kemiskinan yang cenderung mengikat golongan lemah dengan kondisi dimana seseorang atau sekelompok orang laki dan perempuan, yang tidak mampu memenuhi hakhak dasarnya untuk mempertahankan dan mengembangkan kehidupan yang bermartabat. Hak-hak dasar manusia tersebut meliputi: terpenuhinya kebutuhan pangan, sandang, kesehatan, pendidikan, pekerjaran, penunahanair bersih, pertanahan, sumber daya alam dan lingkungan hidup, rasa aman dari perlakuan atau arncaman tindak kekerasan dan hak untuk berpartisipasi dalam kehidupan sosial politik ${ }^{3}$.

Program NTB Bumi Sejuta sapi (BSS) yang dicanangkan oleh pemerintah provinsi NTB pada tahun 2009 lalu disambut positif oleh sekelompok peternak di kabupaten Lombok Barat, yaitu dengan dengan

\footnotetext{
2 Sutrisno, Politik Hukum Perlindungan dan Pengelolaan Lingkungan Hidup, Jurnal Hukum Universitas Islam Indonesia, No. 3 Vol. 18 Juli 2011, hlm. 446 dan 447.

${ }^{3}$ Erwan Agus Purwanto, Mengkaji Potensi Usaha Kecil dan Menengah (UKM) untuk Pembuatan Kebiiakan Anti Kemiskinan di Indonesia, Jurnal Ilmu Sosial dan Ilmu Politik, Volume 10, Nomor 3, Maret 2007, hlm. 300.
} 
membentuk kelompok tani ternak. Dalam pelaksanaan Program BSS, kelempok ternak mendapatkan bantuan sapi dari pemerintah. Pelaksanaan kegiatan secara operasional ditujukan agar kelompok peternak dapat mengembangkan usaha peternakan yang lebih maju dari segi ekonomi maupun budidaya. Sebagai tenaga pendamping dalam pelaksanaan program ini, kelompok didampingi oleh Sarjana Membangun Desa (SMD), untuk mendukung pengembangan usaha dan meningkatkan populasi ternak sapi di Desa sasaran.

Dalam Perjalanannya program BSS banyak mengalami kendala salah satunya tidak meningkatnya pendapatan peternak sapi, sehingga dirubahlah polanya yakni diberikan pada konsorsium salah satunya UD.Wiraguna Ternak Sejahtera yang berperan dalam memberikan pendampingan sehingga diharapkan kedepannya bisa meningkatkan kesejahteraan kelompok peternak sapi. Dengan adanya perjanjian kemitraan ini yang dtandai dengan kontrak kerjasama yang meninmbulkan hak dan kewajiban para pihak sehingga tidak ada yang merasa dirugikan, oleh karena itu penulis tertarik mengkaji mekanisme perjanjian penggemukan sapi dan bentuk perlindungan hukumnya terutama terhadap kelompok peternak sapi.

\section{B. Rumusan Masalah}

Berdasarkan uraian latar belakang diatas dapat dirumuskan permasalahan sebagai berikut :

1. Bagaimana Mekanisme perjanjian kemitraan kelompok peternak sapi dengan UD.Wiraguna Ternak Sejahtera ?

2. Bagaimana Bentuk Perlindungan Hukum Bagi Kelompok Peternak sapi ?

\section{Metode Penelitian}

Penelitian ini, menggunakan metode penelitian Normatif Empiris atau disebut juga dengan metode normatif terapan. Penelitian ini mengkaji pelaksanaan atau implementasi ketentuan hukum positif dan kontrak secara faktual pada setiap peristiwa hukum tertentu yang terjadi dalam masyarakat guna mencapai tujuan yang telah ditentukan. Pengkajian tersebut bertujuan 
untuk memastikan apakah hasil penerapan pada peristiwa hukum in concreto itu sesuai atau tidak sesuai dengan ketentuan undang-undang. Dengan kata lain apakah ketentuan undang-undang telah dilaksanakan sebagaimana patutnya atau tidak, sehingga pihak-pihak yang berkepentingan mencapai tujuannya ${ }^{4}$.

\section{Pembahasan}

\section{Mekanisme Perjanjian Kelompok sapi dengan UD.Wiraguna Ternak Sejahtera}

Pengertian kemitraan dalam Pasal 26 ayat (3) Undang-undang Republik Indonesia Nomor 9 Tahun 1995 tentang Usaha Kecil, adalah : "Kemitraan dilaksanakan dengan disertai pembinaan dan pengembangan dalam salah satu atau lebih bidang produksi dan pengolahan, membantu pemasaran, permodalan, sumber daya manusia, dan teknologi”. Sedangkan ayat (4) adalah: "Dalam melakukan hubungan kemitraan kedua belah pihak mempunyai kedudukan hukum yang setara".

Menurut Mohammad Jafar, dalam kondisi yang ideal, tujuan yang ingin dicapai dalam pelaksanaan kemitraan secara lebih kongkrit adalah. Untuk $^{5}$ :

a. Meningkatkan pendapatan usaha kecil dan masyarakat;

b. Meningkatkan perolehan nilai tambah bagi pelaku kemitraan;

c. Meningkatkan pemerataan dan pemberdayaan masyarakat dan usaha kecil;

d. Meningkatkan pertumbuhan ekonomi pedesaan, wilayah dan nasional;

e. Memperluas kesempatan kerja; dan

f. Meningkatkan ketahanan ekonomi nasional.

Dari difinisi tersebut di atas bahwa "kemitraan" adalah suatu perjanjian hubungan kerjasama usaha yang saling mengikatkan diri antara

\footnotetext{
${ }^{4}$ Fitriyanti F. Wowiling, 2017,Pemenuhan Hak Narapidana Lapas Kelas IIA Manado Berdasarkan Pasal 14 UU No.12 Tahun 1995 Ditinjau Dari Perspektif HAM. JurnalLex Privatum Vol. V/No. 4/Jun/2017 hal 91

${ }^{5}$ Muhammad Jafar, dalam Salim Gofur: Tesis Pelaksanaan Perjanjian Kemitraan antara PT. Malindo dengan Plasma di Kab. Sleman. PMKn. UNDIP, 2010. hlm. 3
} 
pengusaha kecil dengan pengusaha menengah dan/ atau pengusaha besar dalam rangka untuk lebih mempercepat terwujudnya perekonomian nasional yang mandiri dan handal sebagai usaha bersama atas asas kekeluargaan, untuk itu diperlukan upaya-upaya yang lebih nyata untuk menciptakan iklim yang mampu merangsang terselenggaranya usaha yang kokoh diantara semua pelaku kehidupan ekonomi berdasarkan prinsip saling memerlukan, saling memperkuat dan saling menguntungkan.

Wilayah Nusa Tenggara Barat memiliki potensi untuk dikembangkan peternakan khsususnya sapi. Karena alam dan iklim mendukung untuk pengembangan ternak sapi. Salah satu desa tempat penggemukan sapi yaitu desa batu mekar.

Desa Batu Mekar kecamatan Lingsar kabupaten Lombok barat merupakan wilayah sangat mendukung untuk peternakan sapi khususnya penggemukan karena ditopang wilayah subur yang cocok untuk menghasilkan makanan ternak. Di Desa Batu Mekar sendiri terdapat kelompok Ternak sapi GG Land yang anggotanya sebagai berikut :

\begin{tabular}{|l|l|l|}
\hline No & Nama & Keanggotaan \\
\hline 1 & Martono & Ketua \\
\hline 2 & Mustakim & Sekretaris \\
\hline 3 & Triadi astuti & Bendahara \\
\hline 4 & Didik wahyudi & Anggota \\
\hline 5 & Nurman maulana & Anggota \\
\hline 6 & Juhandi & Anggota \\
\hline 7 & Darsah & Anggota \\
\hline 8 & Andi & Anggota \\
\hline 9 & Aulia Fahmi & Anggota \\
\hline 10 & Jumpaelan & Anggota \\
\hline 11 & Amaq Munah & Anggota \\
\hline 12 & Sumi & Anggota \\
\hline 13 & Samsul fikri & Anggota \\
\hline
\end{tabular}




\begin{tabular}{|l|l|l|}
\hline 14 & Rudiman & Anggota \\
\hline 15 & Bulangseh & Anggota \\
\hline 16 & Edwin Sutandi & Anggota \\
\hline 17 & Merah S & Anggota \\
\hline 18 & Ihiya Ulumudin & Anggota \\
\hline
\end{tabular}

Sumber data Desa Batu Mekar Lingsar

Dalam melaksanakan kontrak penggemukan sapi peternak sapi terlebih dahulu membentuk kelompok Ternak sapi. Didesa batu mekar sudah ada kelompok sapi yang dibentuk yang bernama Kelompok Ternak Sapi "GG Land “. Ketua kelompok inilah yang mewakili untuk menandatangani kontrak dengan UD. Wiraguma ternak sejahtera selaku konsultan. Garis Besar Perjanjian Kerjasama Kelompok Penggemukan Sapi. Adapun Alur kerjasamanya melalui sebagai berikut :

a. Masing-masing anggota Kelompok Peternak mendapat pembiayaan dari pihak ke 3 ( Perbankan ) Akad antara Anggota dan Bank

b. Anggota kelombok memberi Kuasa kepada Ketua Kelompok utk bekerjasama dengan pihak ke 3 lainnya (Managemen/ Konsultan sbg Apalis ke pihak bank )

c. Ketua Kelompok sebagai Kuasa seluruh anggota mengadakan Kontrak Kerjasama dengan Manajemen/ Konsultan.

Team Konsultan Mengadakan Kerjasama dengan Kelompok Ternak.Kelompok Ternak memperoleh pembiayaan dari Bank Dana dari bank tersebut dikelola oleh Konsultan untuk pembelian sapi bakalan, pakan, biaya operasional dan sebagainya. Penjualan sapi dilakukan secara bersama dengan kelompok peternak sapi. Dalam Pengembalian keBank merupakan tanggungjawab Konsultan. Ada pembagian hasil antara anggota kelompok dan Konsultan.

Berdasarkan surat perjanjian usaha bersama penggemukan sapi, hak dan kewajiban para pihak, sebagai berikut :

a. Hak dan Kewajiban Pihak UD.Wiraguna Ternak Sejahtera selaku konsultan sebagai berikut : 
1. Mendapatkan bagian sebesar 50\% ( lima puluh persen ) dari keuntungan hasil penjualan dalam kerjasama KEDUA BELAH PIHAK

2. Mengelola seluruh dana pembiayaan dari PIHAK KETIGA yang diterima PIHAK KEDUA untuk dipergunakan bagi kepentingan usaha penggemukan sapi dalam kerjasama ini.

3. Menyiapkan kandang dan mesin pakan sesuai standar teknis usaha penggemukan sapi.

4. Memberikan bimbingan teknis serta bertindak sebagai penjamin usaha penggemukan sapi dalam kerjasama ini.

5. Membeli seluruh sapi hasil Penggemukan dalam kerjasama ini sesuai dengan harga yang disepakati KEDUA BELAH PIHAK.

6. Mengelola pembiayaan yang diperoleh dari Pihak Ketiga ( Bank NTB Syariah) untuk kepentingan jual-beli, pembelian bibit untuk penggemukan dan lain -lain berkenaan dengan usaha ternak sapi PIHAK KEDUA

7. Membeli hasil ternak PIHAK KEDUA sesuai harga pasar

8. Bertanggungjawab dalam pengembalian dana pembiayaan dari Pihak Ketiga ( Bank NTB Syariah )

9. Memperoleh pembagian hasil berupa selisih/ sisa dari hasil yang menjadi hak PIHAK KEDUA

10. Memberikan bimbingan teknis, pengawasan dan pendampingan usaha ternak sapi PIHAK KEDUA

11. Membantu perbaikan dan/ atau perawatan kandang, pengadaan dan perawatan mesin pakan, menyediakan bahan-bahan konsentrat untuk pakan ternak dan bertanggung jawab terhadap kesehatan ternak.

b. Hak dan Kewajiban PIHAK Kelompok peternak sapi yaitu sebagai berikut :

1. Mendapatkan pembagian sebesar 50\% ( lima puluh persen ) dari keuntungan hasil penjualan sapi dalam kerjasama KEDUA BELAH PIHAK

2. Menerima bimbingan teknis usaha penggemukan sapi dari PIHAK PERTAMA 
3. Melakukan seluruh kegiatan penggemukan sapi dan melakukan penjagaan secara bergilir sesuai kesepakatan yang diatur kemudian menyesuaikan dengan kondisi dan situasi di lapangan.

4. Menjual seluruh ternak Sapi hasil kerjasama ini kepada PIHAK PERTAMA sesuai dengan harga yang disepakati KEDUA BELAH PIHAK

5. Memperoleh hasil berupa 1 ( satu ) ekor sapi bakalan pada akhir periode penggemukan / setelah penjualan hasil .

6. Menyerahkan seluruh dana pembiayaan dari Pihak Ketiga untuk dikelola Pihak Pertama yang penggunaannya dikakukan secara bersama hanya untuk kepentingan Ternak Sapi .

7. Merawat ternak sapi, memberi pakan, mengoperasikan mesin pakan dan melakukan penjagaan ternak, yang dilakukan secara bergantian ( shif ) sesuai jadwal yaitu wajib 2 ( dua ) kali setiap anggota dalam 1 ( satu ) minggu, dalam hal pelaksanaannya diatur secara bersama-sama anggota kelompok dengan PIHAK PERTAMA.

8. Menyiapkan hijauan sebagai pakan tambahan berupa rumput gajah, daun lamtoro, gamal dan pakan hijauan lainnya yang dibawa oleh anggota kelompok pada saat jadwal piket kerja.

9. Menjaga kebersihan, kerapihan dan keindahan kandang dan area sekitar .

\section{Bentuk Perlindungan Kelompok Peternak Sapi}

Perlindungan hukum adalah perlindungan akan harkat dan martabat, serta pengakuan terhadap hak-hak asasi manusia yang dimiliki oleh subyek hukum berdasarkan ketentuan hukum dari kesewenangan atau sebagai kumpulan peraturan atau kaidah yang akan dapat melindungi suatu hal dari hal lainnya. Berkaitan dengan konsumen, berarti hukum memberikan perlindungan terhadap hak-hak pelanggan dari sesuatu yang mengakibatkan tidak terpenuhinya hak-hak tersebut.

Perlindungan hukum mereprsentasikan tiga unsur yang menekankan fungsi hukum yaitu kepastian hukum (rechtssicherheit), kemanfaatan (zweck- 
massigkeit), dan keadilan (gerechtigkeit). kepastian hukum merefleksikan penetapan suatu aturan baik tidak tertulis maupun tertulis apabila telah terjadi penyimpangan terhadap suatu peristiwa konkrit. Kemanfaatan ditujukan untuk manfaat dan kegunaan bagi masyarakat. Hukum identik dengan keadilan. Hukum bersifat umum, mengikat setiap orang, bersifat menyamaratakan ${ }^{6}$.

Universalitas perlindungan hukum berupaya melindungi harkat dan martabat manusia dari pemerkosaan yang pada dasarnya serangan hak pada orang lain telah melanggar aturan norma hukum dan undang-undang.24 perlindungan ini menuntut Hukum berfungsi sebagai perlindungan kepentingan manusia. Agar manusia terlindungi, hukum harus dilaksanakan. Pelaksanaan hukum dapat berlangsung secara normal, damai, tetapi dapat terjadi juga karena pelanggaran hukum. Pelanggaran hukum terjadi ketika subjek hukum tertentu tidak menjalankan kewajiban yang seharusnya dijalankan, atau karena melanggar hak-hak subjek hukum lain. Subjek hukum yang dilanggar hak-haknya harus mendapatkan perlindungan hukum.

Indonesia sebagai negara hukum telah dinormativisasi pada Pasal 1 ayat (3) Undang-Undang Dasar 1945 perubahan ke-4 yang menegaskan bahwa "Negara Indonesia adalah negara hukum (rechtsstaat)". Dengan penegasan itu, maka mekanisme kehidupan perorangan, masyarakat, dan negara diatur oleh hukum (tertulis maupun tidak tertulis). Artinya baik anggota masyarakat maupun pemerintah wajib mematuhi hukum tersebut. Negara pada tingkatan ini dituntut tidak hanya bertugas memelihara ketertiban masyarakat, akan tetapi dituntut untuk turut serta aktif dalam semua aspek kehidupan dan penghidupan rakyat. Kewajiban ini merupakan amanat pendiri negara (the founding fathers) Indonesia, seperti dikemukakan pada alines ke4 pembukaan UUD 1945.

Asosiasi yaitu kelompok yang anggotanya mempunyai kesadaran jenis dan ada persamaan kepentingan pribadi maupun kepentingan bersama. Dalam asosiasi, para anggotanya melakukan hubungan sosial, kontak dan komunikasi,

${ }^{6}$ Sudikno Mertokusumo, Bab-Bab Tentang Penemuan Hukum, Citra Adtya Bakti, Bandung, 1993, hlm. 1-2. 
serta memiliki ikatan organisasi formal. Ciri-ciri yang menjadi dasar suatu kelompok dapat dikatakan sebagai sebuah asosiasi adalah sebagai beriku ${ }^{7}$ :

a) Terdapat dorongan atau motif yang sama antar individu satu dengan yang lain.

b) Terdapat akibat-akibat interaksi yang berlainan terhadap individu satu dengan yang lain berdasarkan rasa dan kecakapan yang berbeda-beda antara individu yang terlibat di dalamnya.

c) Adanya penegasan dan pembentukan struktur atau organisasi kelompok yang jelas dan terdiri dari peranan-peranan dan kedudukan masingmasing.

d) Adanya peneguhan norma pedoman tingkah laku anggota kelompok yang mengatur interaksi dalam kegiatan anggota kelompok untuk mencapai tujuan yang ada.

e) Berlangsungnya suatu kepentingan.

f) Adanya pergerakan yang dinamik.

Terwujudnya kemitraan usaha yang kokoh, terutama antara pengusaha besar dan/ atau pengusaha menengah dengan pengusaha kecil, akan lebih memberdayakan pengusaha kecil agar dapat tumbuh dan berkembang semakin kuat dan dapat memantapkan struktur perekonomian nasional yang semakin seimbang berdasarkan demokrasi ekonomi serta mampu meningkatkan kemandirian dan daya saing perekonomian nasional.

Amanat peraturan perundangan yang isinya sangat kondusif bagi tumbuh dan berkembangnya usaha bidang peternakan dengan pola kemitraan ini, dalam prakteknya sangat tidak mudah. Sebagai sebuah perjanjian, hubungan usaha dengan pola kemitraan ini, tidak lepas dari kepentingan usaha pihak yang kuat, yang sering mengabaikan pihak yang lemah.

Menurut Suharti sebagaimana dikutip oleh Yulien Tika Fitriza, F. Trisakti Haryadi, dan Suci Paramitasari Syahlani ${ }^{8}$... "model kemitraan yang dilakukan oleh inti adalah melalui penyediaan sarana produksi peternakan, bimbingan teknis dan manajemen, menampung serta memasar-kan hasil produksi. Peternak plasma menyediakan kandang, melakukan kegiatan

\footnotetext{
${ }^{7}$ Rudy Hendra Pakpahan dan Eka N. A. M. Sihombing, Tanggung Jawab Negara dalam Pelaksanaan Jaminan Sosial, Jurnal Legislasi Indonesia, Vol. 9 No. 2 - Juli 2012, hlm. 168.

${ }^{8}$ Suharti. Analisis profitabilitas usaha ayam pedaging pola kemitraan di Kabupaten Magelang.

Tesis S-2. Fakultas Peternakan Universitas Gadjah Mada. Yogyakarta. 2003.
} 
budidaya dan hasil dari penjualan ayam diserahkan kepada pihak inti dengan harga yang telah disesuaikan pada isi kontrak perjanjian kerjasama.

Permasalahan dalam model kemitraan sering menyebabkan keluhan dan kecurigaan yang menimbulkan perdebatan. Pengembangan sebuah pola kemitraan didasarkan pada visi dan misi yang di-bentuk dari persepsi inti (perusahaan) terhadap kemitraan yang tercermin dalam kontrak perjanjian yang telah dibuat dengan mempertimbangkan resiko yang akan dihadapi oleh inti.

Perjanjian kemitraan sebagai salah satu model "perjanjian baku" cenderung menjadi cerminan kepentingan (visi misi) dari pihak perusahan inti yang mempunyai posisi dominan dan pembentukan dan pelaksanaan perjanjian.

Praktek bisnis yang berat sebelah yang diawali oleh adanya perjanjian baku yang tidak memberikan keseimbangan kepentingan bagi para pihak, memunculkan reaksi yang mengarah perlunya diberikan tempat yang "layak" bagi keberadaan asas itikad baik dan kepatutan dalam pembuatan maupun pelaksanaan perjanjian. Sebagaimana tercantum dalam Pasal 1338 ayat 3 KUH Perdata Persetujuan harus dilaksanakan dengan itikhad baik.

Pasal 1339 KUH Perdata menegaskan bahwa perjanjian itu tidak semata mata tunduk pada apa yang dituliskan akan tetapi juga mengikat halhal yang dengan tegas dinyatakan di dalamnya, tetapi juga untuk segala sesuatu yang menurut sifat persetujuan diharuskan oleh kepatutan, kebiasaan dan undang-undang.

Secara normatif, hampir semua perjanjian yang dibuat oleh pelaku bisnis, termasuk perjanjian kemitraan bidang peternakan ini telah sah menurut ketentuan Pasal 1320 KUH Perdata. Perjanjian kemitraan bidang peternakan telah memenuhi syarat subyektif perjanjian yaitu (1) sepakat dan (2) cakap dan juga telah memenuhi syarat obyektif yaitu (3) hal tertentu dan (4) kausa halal.

Permasalahan muncul ketika pembuatan perjanjian yang bersifat baku ini hanya dibuat oleh pihak inti sebagai pihak yang dominan. Plasma sebagai pihak yang relatif lemah hanya bisa "take it or leave it" tanpa bisa 
melakukan penawaran apalagi merubah isi pasal-pasal dalam perjanjian kemitraan tersebut.

Perjanjian baku pada dasarnya tidak dilarang, dengan alasan efisiensi maka pejanjian baku selalu diterapkan dalam hampir semua perjanjianyang ada saat ini.18 Perjanjian yang lebih banyak bersifat adhesi ini tidak memberi ruang kepada pihak yang lemah untuk melakukan proses negosiasi sebagaiman mestinya. Menerima atau menolak (take it or leave it) merupakan satu satunya pilihan bagi pihak yang lemah posisi tawarnya. Penyimpangan yang sering mendompleng pada perjanjian baku adalah dicantumkannya klausula eksonerasi (exemption clauses), yaitu suatu pasal atau ketentuan yang isinya berupa pemabatasan tanggung jawab atau bahkan pembebasan tanggung jawab salah satu pihak terhadap pihak yang lain. Penyimpangan ini juga merupakan dampak negatif dari penerapan asas Kebebasan Berkontrak yang tidak terkontrol dengan baik.

Berikut ini adalah salah Isi perjanjian kontrak Sapi dalam pasal 5 yang berbunyi “Apabila terjadi suatu kondisi yang memaksa ( Force Major) seperti Gempa Bumi, Tanah Longsor, Huru-Hara, Pandemi dan kondisi memaksa lainnya yang mengakibatkan kerjasama ini tidak bisa berjalan sebagaimana mestinya, maka Kedua Belah Pihak sepakat tidak melakukan tuntutan apapun antara satu pihak dengan pihak lainnya"

Klausula seperti ini tidak jelas karena bencana alam tidak dapat diukur tingkat kerusakannya, sehingga akan merugikan kedua belah pihak. Dan ini harusnya dalam keadaan Force Major harus lebih didetailkan sehingga ada opsi opsi yang harus dicantumkan dalam perjanjian untuk meminimalisir dampak kerugian. Ini tidak sesuai dan bertentangan dengan Pasal 1338 ayat (3) KUHPerdata, yaitu bahwa "suatu perjanjian harus dilaksanakan dengan itikat baik".

Sedang menurut Subekti, asas itikad baik dijelaskan sebagai berikut : "Itikad baik dalam pelaksanaan perjanjian adalah berarti kepatutan, yaitu penilaian baik, terhadap tindakan salah satu pihak dalam melaksanakan apa 
yang telah diperjanjikan dan bertujuan untuk mencegah perbuatan yang tidak patut dan sewenang-wenang dari salah satu pihak yang lain"'”.

Undang-undang Nomor 20 tahun 2008 tentang Usaha Mikro, Kecil, Menengah yang menggantikan undang-undang Nomor 9 tahun 1995 dalam Pasal 1 angka 13 meyebutkan, Kemitraan adalah kerjasama dalam keterkaitan usaha, baik langsung maupun tidak langsung, atas dasar prinsip saling memerlukan, mempercayai, memperkuat, dan menguntungkan yang melibatkan pelaku Usaha Mikro, Kecil, dan Menengah dengan Usaha Besar.

Pasal 3 Peraturan Pemerintah Republik Indonesia Nomor 44 Tahun 1997 tentang Kemitraan, disebutkan pola kemitraan inti plasma adalah: "Pengusaha besar dan/ atau pengusaha menengah sebagai inti melakukan pembinaan dan mengembangkan pengusaha kecil yang menjadi plasmanya".

Dalam Pembahasan dari sisi hukum perjanjian secara lebih mendalam maka perjanjian/pasal dalam perjanjian yang secara normatif telah memenuhi syarat sah perjanjian (Pasal 1320 KUH Perdata) akan tetapi ternyata telah melanggar isi Pasal 1338 KUH Perdata, khususnya ketentuan tentang itikad baik.

Perjanjian yang melanggar asas itikad baik pada pada dasarnya mempunyai dua kemungkinan untuk batal, jika dianggap melanggar syarat subyektif (dalam hal ini tidak ada kesepakatan, karena adanya cacat kehendak) maka perjanjian itu dapat dibatalkan. Berbeda halnya jika perjanjian itu dianggap telah melanggar syarat obyektif sebagai mana diatur dalam Pasal 1337 "tentang sebab tidak halal” maka perjanjian itu dapat dibatalkan.

Perjanjian yang dibuat kelompok Ternak sapi dengan UD Wiraguna Ternak sejahtera memberikan perlindungan hukum salah satunya mekanisme penyelesaian sengketa yang apabila musyawarah tidak tercapai dapat menempuh jalur hukum yakni melalui Pengadilan Negeri Mataram dengan demikian kepastian hukum dapat tercapai.

\footnotetext{
${ }^{9}$ Subekti, Hukum Perjanjian, Jakarta, Internusa, 2002, hlm. 39
} 


\section{E. Kesimpulan}

Berdasarkan Pembahasan diatas dapat disimpulkan sebagai berikut : Mekanisme perjanjian penggemukan sapi antara kelompok peternak sapi dengan UD Ternak sejahtera (konsultan) diawali dengan membentuk kelompok, ketua kelompok inilah yang mewakili pembuatan perjanjian dengan konsultan yang akan memberikan pendampingan selama program penggemukan sapi. Upaya perlindungan hukum bagi para pihak, khususnya pihak Plasma sebagai pihak yang lemah dapat ditempuh melalui tiga mekanisme, yaitu (a)Penerapan ketentuan hukum administrasi dengan penegakkan aturan tentang, pembinaan, pengawasan oleh pemerintah, sebagai mana diatur dalam UU usaha mikro, kecil dan menengah, dan atau PP tentang kemitraan. (b)Penerapan ketentuan dalam UU no 8 tahun 1999 tentang Perlindungan konsumen. (c) Penerapan ketentuan hukum perdata, dengan melakukan gugatan pembatalan perjanjian ke Pengadilan Negeri.

\section{Daftar Pustaka}

Erwan Agus Purwanto, 2007.Mengkaji Potensi Usaha Kecil dan Menengah (UKM) untuk Pembuatan Kebiiakan Anti Kemiskinan di Indonesia, Jurnal Ilmu Sosial dan Ilmu Politik, Volume 10, Nomor 3, Maret 2007

Fitriyanti F. Wowiling, 2017,Pemenuhan Hak Narapidana Lapas Kelas IIA Manado Berdasarkan Pasal 14 UU No.12 Tahun 1995 Ditinjau Dari Perspektif HAM. JurnalLex Privatum Vol. V/No. 4/Jun/2017

Moleong, Lexy J. 2009. Metodologi Penelitian Kualitatif. Bandung: Remajaa Rosdakarya

Muhammad Jafar, dalam Salim Gofur: 2010.Tesis Pelaksanaan Perjanjian Kemitraan antara PT. Malindo dengan Plasma di Kab. Sleman. PMKn. UNDIP

Rudy Hendra Pakpahan dan Eka N. A. M. Sihombing, Tanggung Jawab Negara dalam Pelaksanaan Jaminan Sosial, Jurnal Legislasi Indonesia, Vol. 9 No. 2 - Juli 2012,

Satrio. J.1992. Hukum Perjanjian (Perjanjian Pada Umumnya). Bandung: PT. Cipta Aditya Bakti 
Sajipto Raharjo.2000. Ilmu Hukum.Citra Aditya Bakti :Bandung

Setiono. 2014.Rule Of Law (Supremasi Hukum), Magister Ilmu Hukum Program Pascasarjana Universitas Sebelas Maret : Surakarta.

Sutrisno, Politik Hukum Perlindungan dan Pengelolaan Lingkungan Hidup, Jurnal Hukum Universitas Islam Indonesia, No. 3 Vol. 18 Juli 2011

Subekti, 2002. Hukum Perjanjian, Jakarta, Internusa,

Suharti.2003. Analisis profitabilitas usaha ayam pedaging pola kemitraan di Kabupaten Magelang. Tesis S-2. Fakultas Peternakan Universitas Gadjah Mada. Yogyakarta.

Soemitro, Ronny Hanitijo. 1990. Metodologi Penelitian Hukum dan Jurimetri Jakarta: Ghalia Indonesia

Sudikno Mertokusumo, 1993.Bab-Bab Tentang Penemuan Hukum, Citra Adtya Bakti, Bandung,

\section{Peraturan Perundang Undangan}

Indonesia Undang-undang Republik Indonesia Nomor 9 Tahun 1995 tentang Usaha Kecil

Tjitrosudibio. 2008. Kitab Undang-Undang Hukum Perdata. Jakarta: PT Pradnya Paramita.

Indonesia Undang-undang Nomor 20 tahun 2008 tentang Usaha Mikro, Kecil, Menengah

Indonesia, Undang-Undang Nomor 18 Tahun 2009 tentang Peternakan Dan Kesehatan Hewan

Indonesia Undang undang nomor 8 tahun 1999 tentang Perlindungan konsumen 